\title{
Review \\ Paving the Way for Fertilization: The Role of the Transmitting Tract
}

\author{
Ana Marta Pereira ${ }^{1,2, *(\mathbb{D}}$, Diana Moreira ${ }^{2,3} \mathbb{C}$, Sílvia Coimbra $^{2,3}$ and Simona Masiero ${ }^{1}$ \\ 1 Dipartimento di Bioscienze, Università Degli Studi di Milano, 20133 Milano, Italy; simona.masiero@unimi.it \\ 2 LAQV Requimte, Sustainable Chemistry, Universidade do Porto, 4169-007 Porto, Portugal; \\ dianamoreira@fc.up.pt (D.M.); scoimbra@fc.up.pt (S.C.) \\ 3 Faculdade de Ciências da Universidade do Porto, Departamento de Biologia, Universidade do Porto, \\ rua do Campo Alegre, 4169-007 Porto, Portugal \\ * Correspondence: ambacpereira@fc.up.pt
}

Citation: Pereira, A.M.; Moreira, D.; Coimbra, S.; Masiero, S. Paving the Way for Fertilization: The Role of the Transmitting Tract. Int. J. Mol. Sci. 2021, 22, 2603. https://doi.org/ $10.3390 /$ ijms 22052603

\section{Academic Editor:}

Alfonso Gutiérrez-Adán

Received: 28 January 2021

Accepted: 2 March 2021

Published: 5 March 2021

Publisher's Note: MDPI stays neutral with regard to jurisdictional claims in published maps and institutional affiliations.

Copyright: (c) 2021 by the authors. Licensee MDPI, Basel, Switzerland. This article is an open access article distributed under the terms and conditions of the Creative Commons Attribution (CC BY) license (https:/ / creativecommons.org/licenses/by/ $4.0 /)$.

\begin{abstract}
Angiosperm reproduction relies on the precise growth of the pollen tube through different pistil tissues carrying two sperm cells into the ovules' embryo sac, where they fuse with the egg and the central cell to accomplish double fertilization and ultimately initiate seed development. A network of intrinsic and tightly regulated communication and signaling cascades, which mediate continuous interactions between the pollen tube and the sporophytic and gametophytic female tissues, ensures the fast and meticulous growth of pollen tubes along the pistil, until it reaches the ovule embryo sac. Most of the pollen tube growth occurs in a specialized tissue- the transmitting tract-connecting the stigma, the style, and the ovary. This tissue is composed of highly secretory cells responsible for producing an extensive extracellular matrix. This multifaceted matrix is proposed to support and provide nutrition and adhesion for pollen tube growth and guidance. Insights pertaining to the mechanisms that underlie these processes remain sparse due to the difficulty of accessing and manipulating the female sporophytic tissues enclosed in the pistil. Here, we summarize the current knowledge on this key step of reproduction in flowering plants with special emphasis on the female transmitting tract tissue.
\end{abstract}

Keywords: plant reproduction; reproductive tract; transmitting tissue; pollen tube growth; extracellular matrix; pollen tube guidance

\section{Introduction}

Reproductive success is vital for seed formation in angiosperms. Seeds are the product of double fertilization, a process unique to angiosperms, where one sperm cell fuses with the egg cell to produce the embryo while a second sperm cell fuses with the central cell to form the endosperm, a nutritive tissue essential for the growth and development of the next generation [1].

Angiosperm reproduction begins when a pollen grain alights on the top of the stigmatic cells, where it adheres and hydrates, leading to the germination of the pollen tube (PT). The PT carries the two sperm cells through different female reproductive tissues-the stigma, the style, and the transmitting tract (TT) - and then it grows along the funiculus [2], reaching the ovule micropyle. After perceiving the embryo sac attraction signal, the PT moves into the ovule and penetrates the embryo sac through one of its synergids. After the PT bursts inside the receptive synergid, the sperm cells are released and fuse with the female gametes, initiating seed development [3-6]. The entrance of more than one PT into an embryo sac is tightly controlled, and late-arriving PTs' entrance is prevented $[7,8]$.

This reproductive process involves a rich network of intrinsic communications and signaling cascades that mediate interactions between the PT and the sporophytic and gametophytic female tissues, ensuring the fast and meticulous growth of the PT along the pistil tissues. A considerable part of PT growth and its interactions with female tissues 
occur in the TT, which plays a pivotal role in the successful completion of the fertilization process. PT guidance in the extracellular matrix of the TT pathway, from the stigma to the embryo sac, is known to occur without any influence from the target ovule and is defined as the "pre-ovular guidance" stage $[9,10]$. Actually, the TT constitutes a key innovation in flowering plants, being essential for their reproductive success. The advent of the TT is closely associated with the evolutionary origin of carpels and the process of postgenital fusion of the carpellary flanks [11].

This is not only a major step in angiosperm evolution, but it also offers a perfect opportunity for manipulation of pollination and PT growth, an invaluable tool in plant breeding programs. In Arabidopsis, the TT includes cylindrical cells and is composed of highly secretory cells characterized by an extensive extracellular matrix (ECM), forming a highway for the PTs to grow inside the pistil $[12,13]$. This multifaceted matrix is proposed to support and provide nutrition and adhesion for PT growth and guidance, being also a place of species recognition [14-18].

Despite the current advances in plant reproduction, there is certainly much more to know about the fundamental molecular mechanisms that regulate the interactions of the PTs within the female reproductive tract. Fascinating questions raised over the years about TT functions, namely the roles of the molecules present in this tissue, do not yet have answers. Here, we summarize the origin and formation of the TT and the most recent results on its important functions for the reproductive process.

\section{The Transmitting Tract}

The TT is a specialized structure, starting at the base of the stigma, running down from the apex to the base of the ovary [19]. The TT is one of the marginal tissues of the gynoecium, along with the septum, style, and stigma. It arises from a specialized tissue within the carpel margins with meristematic characteristics: the carpel margin meristem (CMM). In Arabidopsis, the gynoecium is formed by two congenitally fused carpels which elongate to form a cylindrical structure during its development. In the adaxial side of this cylindrical structure, from both sides, two internal ridges develop, the CMMs, towards the center of the gynoecium to eventually meet and fuse, forming the septum through postgenital fusion. On the borders of these CMMs, the placenta develops and gives rise to the ovule primordia and later to fully mature ovules. Only after the gynoecium fully closes do the TT and the style differentiate, generating a fully mature gynoecium [20-22].

TT structure varies in the different types of styles; styles are classified as open or closed or semi-closed [12], depending on whether they are formed by a hollow channel or lumen, surrounded by a secretory epidermis (the transmitting tissue cells) that lines the canal producing mucilage (Figure $1 \mathrm{~b}, \mathrm{~d}$ ), such as in the lily, or formed by several layers of secretory tissue (the transmitting tissue), with a very small lumen but with large quantities of intercellular secretions (Figure 1a,c), such as in Arabidopsis. In both cases, narrow, elongated secretory cells, separated by the produced mucilage in the open styles and the ECM in the closed styles, form the transmitting tissue. Usually, these elongated cells communicate with each other, mostly through plasmodesmata localized in the transverse walls but not along its longitudinal walls. This type of cell organization presented by the TT is thought to be specially designed to facilitate PT growth along this tissue, providing them with a pathway of minimum resistance [18]. The presence of plasmodesmata is thought to be connected to the TT function in several ovary signal transduction pathways essential for pollen tube growth control and coordination [23]. Developmentally regulated programmed cell death (PCD) of the TT cells also contributes to the facilitation of PT growth. It seems to provide a smoother and more accommodating pathway for PTs to grow along this tissue and reach the ovules. Moreover, the deterioration of the TT cells is thought to be responsible for an increase in nutrient resource availability in the ECM to nurture the growing PTs. Furthermore, TT PCD is believed to have a protective role regarding fruit and seed set, by preventing the entrance of pathogens into the ovary, which would otherwise compromise fruit and seed development [24]. In Arabidopsis, TT PCD starts before anthesis and it 
seems to be enhanced by pollination [25], but in tobacco, it is triggered by pollination [24]; nevertheless, both studies pinpoint that this PCD is developmentally controlled and very specific for the TT.

a

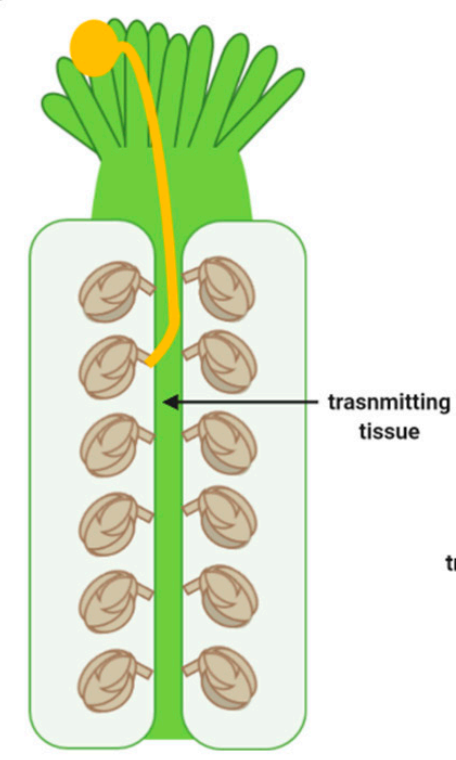

C

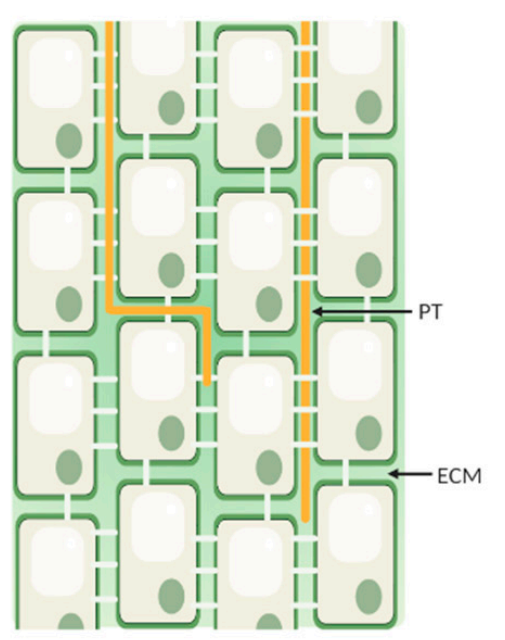

b

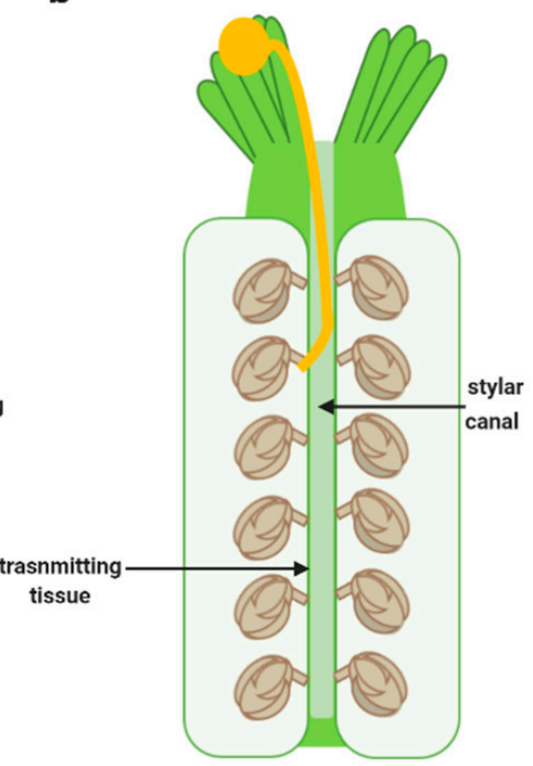

d

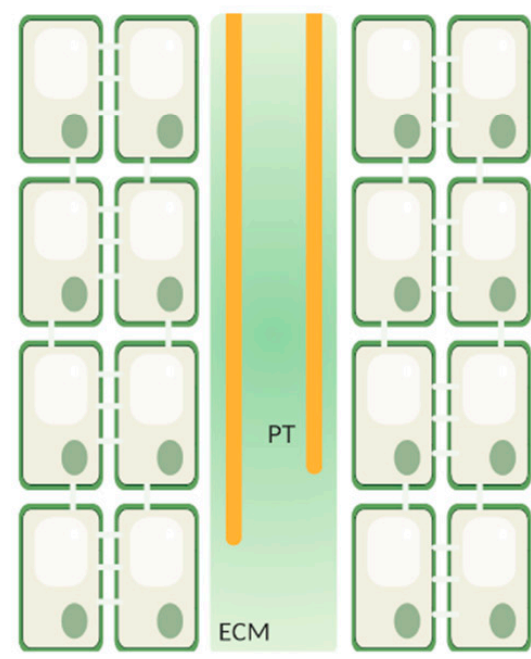

Figure 1. Schematic representation of a closed and an open style. (a) Longitudinal section of a closed style showing a continuous strand of transmitting tissue inside the pistil. A pollen grain is represented germinating in the stigmatic cells, with a pollen tube (in yellow) growing through the transmitting tract tissue towards the ovules. (b) Longitudinal section of an open style showing a continuous stylar canal lined with a secretory epidermis. A pollen grain is shown germinating in the stigmatic cells, with a pollen tube (in yellow) directing towards the ovules at the surface of the canal cells. (c) Longitudinal section of a part of the transmitting tissue from a closed style exhibiting the presence of substantial intercellular spaces filled with the extracellular matrix. Elongated cells are shown; they are connected through each other by the plasmodesmata in its transverse walls. Pollen tubes (PT) (shown in yellow) are displayed growing between the cells, in the extracellular matrix (ECM). (d) Longitudinal section of an open style showing the epidermal layer of secretory cells lining a canal filled with extracellular matrix (ECM); the pollen tube (PT) is yellow. Created with BioRender.com (accessed on 25 February 2021). 
Numerous studies have described the importance of a large set of transcription factors and regulators controlling TT formation and development, giving also important insights into its functions in reproduction. Given the origin and localization of the TT in the carpel, any mutation affecting genes whose products are essential for carpel fusion and development will affect TT development and formation too. Transcription regulators such as ETTIN, SPATULA, SEUSS, and AINTEGUMENTA [21,26,27] are just some examples of genes which are essential for the correct development of the gynoecium and consequently for TT development. Sessions and Zambryski [24] have shown that in ettin (auxin response transcription factor) mutant carpels, an everted TT develops in valve tissues and on regions with missing valves. Although misplaced, this TT seems to be functionally active since PTs can be seen growing along this tissue by aniline blue staining. SPATULA (SPT), a basic helix-loop-helix (bHLH) transcription factor, is fundamental for TT differentiation $[21,28]$, since spt mutant carpels lack a TT and exhibit defects in the postgenital fusion of the septum. Moreover, the transcription adaptor SEUSS and the transcription factor AINTEGUMENTA play a role in TT formation; around $50 \%$ of the seu-3 ant-1 gynoecia do not develop a TT [29]. Over the years, many other genes crucial for correct gynoecium development were described to be essential for TT establishment, such as ALCATRAZ [30] and INDEHISCENT [31].

Crawford and collaborators [25], in an elegant study, have shown that NO TRANSMITTING TRACT (NTT), which encodes a C2H2/C2HC zinc finger transcription factor specifically expressed in the TT, is essential for its correct development. Arabidopsis $n t t$ mutant plants lack a functional TT, showing impaired PT growth in the pistil due to defective ECM production and defective PCD. In the $n t t$ mutant plants, the lack of a functional TT in the pistil is accompanied by a reduced staining for acidic polysaccharides by alcian blue in this region, indicating reduced arabinogalactan protein (AGP) content, considered essential for its functionality [32] and implicating them in this PCD process [19,25]. AGP involvement in this step must be verified by other methods, such as staining with the Yariv reagent or immunolocalization studies.

Besides NTT, several other genes contribute to the correct development of the TT, such as the redundant HECATE (HEC1, HEC2, HEC3) genes [33] and the closely related bHLH transcription factors, HALF FILLED (HAF), also known as CESTA (CES) and BRASSINOSTEROID ENHANCED EXPRESSION1 (BEE1) and BEE3 [34]. HEC gene products modulate postgenital fusion of the septum and consequently TT development; HEC genes interact with SPT and together specify TT formation and development. As well as HEC transcription factors, HAF, BEE1, and BEE3 redundantly specify TT formation, being involved in ECM production, and besides this, they modulate cell death in the TT [34,35]. Recently, the MADS-box transcription factor SEEDSTICK was shown to act with NTT in the TT cell degradation process [36]. STK modulates TT development, acting together with CES, $B E E 1$, and BEE3 [37]. STK and CES influence PCD in the TT; in fact, the quadruple mutant bee1 bee3 stk ces-4 transcriptome pinpoints that several genes whose products are involved in cell death are downregulated. Gene interaction studies have allowed Crawford and Yanofsky [34] to propose an elegant model describing the concerned action of these genes in reproductive tract development, which has now been suitably updated by Di Marzo and collaborators [37], including STK.

As stated above, any gene which might be involved in carpel fusion might cause indirect defects in TT development. With this brief depiction of TT formation and development, we only show a small portion of the knowledge about this process, which is much more complex and finely regulated, involving the interaction of these regulatory gene networks with hormone signaling, such as auxin, cytokinin, and brassinosteroids. This has been extensively reviewed in $[22,34,35]$. The more recent work demonstrated the AHK cytokinin receptors expressed in the gynoecium to have redundant and specialized functions in this tissue of Arabidopsis [38]. Many genes have already been studied (Table 1 and Figure 2), but many more remain to be identified. Studies on this topic have contributed to a better understanding of the reproductive process, opening roads for others to study what goes on 
inside this tissue regarding PT growth, support, and guidance in greater detail, as will be discussed in the next section.

Table 1. List of the key players that are involved in TT formation and development in Arabidopsis thaliana.

\begin{tabular}{|c|c|c|c|c|c|}
\hline Proteins & Type & Function & $\begin{array}{l}\text { Expression } \\
\text { Pattern }\end{array}$ & $\begin{array}{c}\text { Phenotype of } \\
\text { Loss-of-Function } \\
\text { Mutants }\end{array}$ & References \\
\hline $\begin{array}{c}\text { NO } \\
\text { TRANSMITING } \\
\text { TRACT (NTT) }\end{array}$ & $\begin{array}{l}\mathrm{C} 2 \mathrm{H} 2 / \mathrm{C} 2 \mathrm{HC} \text { zinc } \\
\text { finger transcription } \\
\text { factor }\end{array}$ & $\begin{array}{c}\text { Transmitting tract (TT) } \\
\text { development; } \\
\text { extracellular matrix } \\
\text { (ECM) production and } \\
\text { TT programed cell } \\
\text { death (PCD) }\end{array}$ & TT & $\begin{array}{c}\text { Non functional } \\
\text { TTdefective ECM } \\
\text { production and defective } \\
\text { PCD }\end{array}$ & [25] \\
\hline ETTIN (ETT) & $\begin{array}{l}\text { Auxin response } \\
\text { transcription factor }\end{array}$ & $\begin{array}{l}\text { Correct gynoecium } \\
\text { formation }\end{array}$ & $\begin{array}{l}\text { Gynoecium; } \\
\text { valves; } \\
\text { developing } \\
\text { ovules }\end{array}$ & $\begin{array}{l}\text { Everted TT develops in } \\
\text { valve tissues \& on regions } \\
\text { with missing valves }\end{array}$ & [26] \\
\hline SPATULA (SPT) & $\begin{array}{c}\text { bHLH (basic } \\
\text { helix-loop-helix) } \\
\text { transcription factor }\end{array}$ & $\begin{array}{l}\text { Acts redundantly with } \\
A L C \text { to control } \\
\text { development of carpel } \\
\text { margin tissues }\end{array}$ & $\begin{array}{l}\text { Developing } \\
\text { carpel margin } \\
\text { tissues }\end{array}$ & $\begin{array}{l}\text { Unfused carpels; TT is } \\
\text { absent; exhibits defects in } \\
\text { post-genital fusion of the } \\
\text { septum }\end{array}$ & {$[21,28]$} \\
\hline SEUSS (SEU) & $\begin{array}{l}\text { Transcriptional } \\
\text { co-regulator }\end{array}$ & $\begin{array}{l}\text { Development of the } \\
\text { carpel margin } \\
\text { meristem } \\
\text { (meristematic } \\
\text { structure located on } \\
\text { the margins of the } \\
\text { fused carpels and } \\
\text { gives rise to ovules, } \\
\text { septum, and TT) }\end{array}$ & $\begin{array}{l}\text { Carpel margin } \\
\text { meristem and } \\
\text { ovules }\end{array}$ & $\begin{array}{l}\text { Partial splitting of the } \\
\text { gynoecial apex; seu ant } \\
\text { double mutants exhibit } \\
\text { ovule defects \& } 50 \% \text { of the } \\
\text { gynoecia do not develop a } \\
\text { TT }\end{array}$ & [29] \\
\hline $\begin{array}{l}\text { AINTEGUMENTA } \\
\text { (ANT) }\end{array}$ & $\begin{array}{l}\text { Putative } \\
\text { transcriptional } \\
\text { regulator }\end{array}$ & $\begin{array}{l}\text { Ovule development; } \\
\text { TT development }\end{array}$ & $\begin{array}{l}\text { Floral organs } \\
\text { primordia \& } \\
\text { developing } \\
\text { ovules. }\end{array}$ & $\begin{array}{l}\text { Fail to produce ovules } \\
\text { with integuments \& } \\
\text { functional female } \\
\text { gametophyte; seu ant } \\
\text { double mutants exhibit } \\
\text { ovule defects \& } 50 \% \text { of the } \\
\text { gynoecia do not develop a } \\
\text { TT }\end{array}$ & [29] \\
\hline $\begin{array}{l}\text { ALCATRAZ } \\
\text { (ALC) }\end{array}$ & $\begin{array}{l}\text { myc/bHLH } \\
\text { transcription } \\
\text { factor-like protein }\end{array}$ & $\begin{array}{l}\text { Acts redundantly with } \\
\text { SPT to control } \\
\text { development of carpel } \\
\text { margin tissues; fruit } \\
\text { dehiscence }\end{array}$ & $\begin{array}{l}\text { Developing } \\
\text { carpel margin } \\
\text { tissues; TT; } \\
\text { stigma }\end{array}$ & $\begin{array}{l}\text { Disruption of septum \& } \\
\text { gynoecium fusion; defects } \\
\text { in TT development. Fruit } \\
\text { dehiscence impaired }\end{array}$ & [30] \\
\hline $\begin{array}{l}\text { INDEHISCENT } \\
\text { (IND) }\end{array}$ & $\begin{array}{l}\text { bHLH } \\
\text { DNA-binding } \\
\text { superfamily } \\
\text { protein }\end{array}$ & $\begin{array}{c}\text { Valve margin } \\
\text { development and } \\
\text { silique dehiscence. TT } \\
\text { development }\end{array}$ & Valve margins & $\begin{array}{l}\text { Disruption of septum and } \\
\text { gynoecium fusion. Fruits } \\
\text { fail to open on maturity. }\end{array}$ & [31] \\
\hline $\begin{array}{c}\text { HECATE } 1,2 \text { and } \\
3 \text { (HEC1, HEC2, } \\
\text { HEC } 3)\end{array}$ & $\begin{array}{l}\text { bHLH } \\
\text { transcription } \\
\text { factors }\end{array}$ & $\begin{array}{l}\text { Modulate post-genital } \\
\text { fusion of the septum, } \\
\text { and consequently TT } \\
\text { development }\end{array}$ & $\begin{array}{l}\text { Developing } \\
\text { septum, TT } \\
\text { and ovules }\end{array}$ & $\begin{array}{l}\text { Infertility, defects in } \\
\text { septum, TT and stigma } \\
\text { development and } \\
\text { impaired pollen tube } \\
\text { growth }\end{array}$ & [33] \\
\hline
\end{tabular}


Table 1. Cont.

\begin{tabular}{|c|c|c|c|c|c|}
\hline Proteins & Type & Function & $\begin{array}{l}\text { Expression } \\
\text { Pattern }\end{array}$ & $\begin{array}{c}\text { Phenotype of } \\
\text { Loss-of-Function } \\
\text { Mutants }\end{array}$ & References \\
\hline $\begin{array}{c}\text { HALF FILLED } \\
\text { (HAF) / CESTA } \\
\text { (CES) }\end{array}$ & $\begin{array}{l}\text { Transcription } \\
\text { factor }\end{array}$ & $\begin{array}{l}\text { Acts redundantly with } \\
\text { BEE1 \& BEE3 to } \\
\text { specify reproductive } \\
\text { tract tissues }\end{array}$ & $\begin{array}{c}\text { Septum, TT } \\
\text { and funiculus }\end{array}$ & $\begin{array}{l}\text { In haf bee1 bee3 ECM } \\
\text { formation and PCD fail to } \\
\text { occur within the TT; } \\
\text { reduced pollen tube } \\
\text { growth }\end{array}$ & [34] \\
\hline $\begin{array}{l}\text { BRASSINOS- } \\
\text { TEROID } \\
\text { ENHANCED } \\
\text { EXPRESSION1 } \\
\text { and } 3 \text { (BEE1, } \\
\text { BEE3) }\end{array}$ & $\begin{array}{c}\text { bHLH } \\
\text { transcription factor }\end{array}$ & $\begin{array}{l}\text { Acts redundantly with } \\
\text { HAF to specify } \\
\text { reproductive tract } \\
\text { tissues }\end{array}$ & $\begin{array}{l}\text { BEE1: stigma \& } \\
\text { top of the } \\
\text { style.BEE3 TT } \\
\text { and style.: }\end{array}$ & $\begin{array}{l}\text { In haf bee1 bee3 ECM } \\
\text { formation and PCD fail to } \\
\text { occur within the TT; } \\
\text { reduced pollen tube } \\
\text { growth }\end{array}$ & [34] \\
\hline $\begin{array}{l}\text { SEEDSTICK } \\
\text { (STK) }\end{array}$ & $\begin{array}{c}\text { MADS-box } \\
\text { transcription factor }\end{array}$ & $\begin{array}{l}\text { Ovule identity; normal } \\
\text { seed shedding; seed } \\
\text { coat development; TT } \\
\text { PCD }\end{array}$ & $\begin{array}{l}\text { Septum and } \\
\text { ovules }\end{array}$ & $\begin{array}{l}\text { Fail to release seeds; } \\
\text { Separation of abscission } \\
\text { zone cells fails; fruits are } \\
\text { shorter; abnormal } \\
\text { positioning of seeds }\end{array}$ & {$[36,37]$} \\
\hline
\end{tabular}
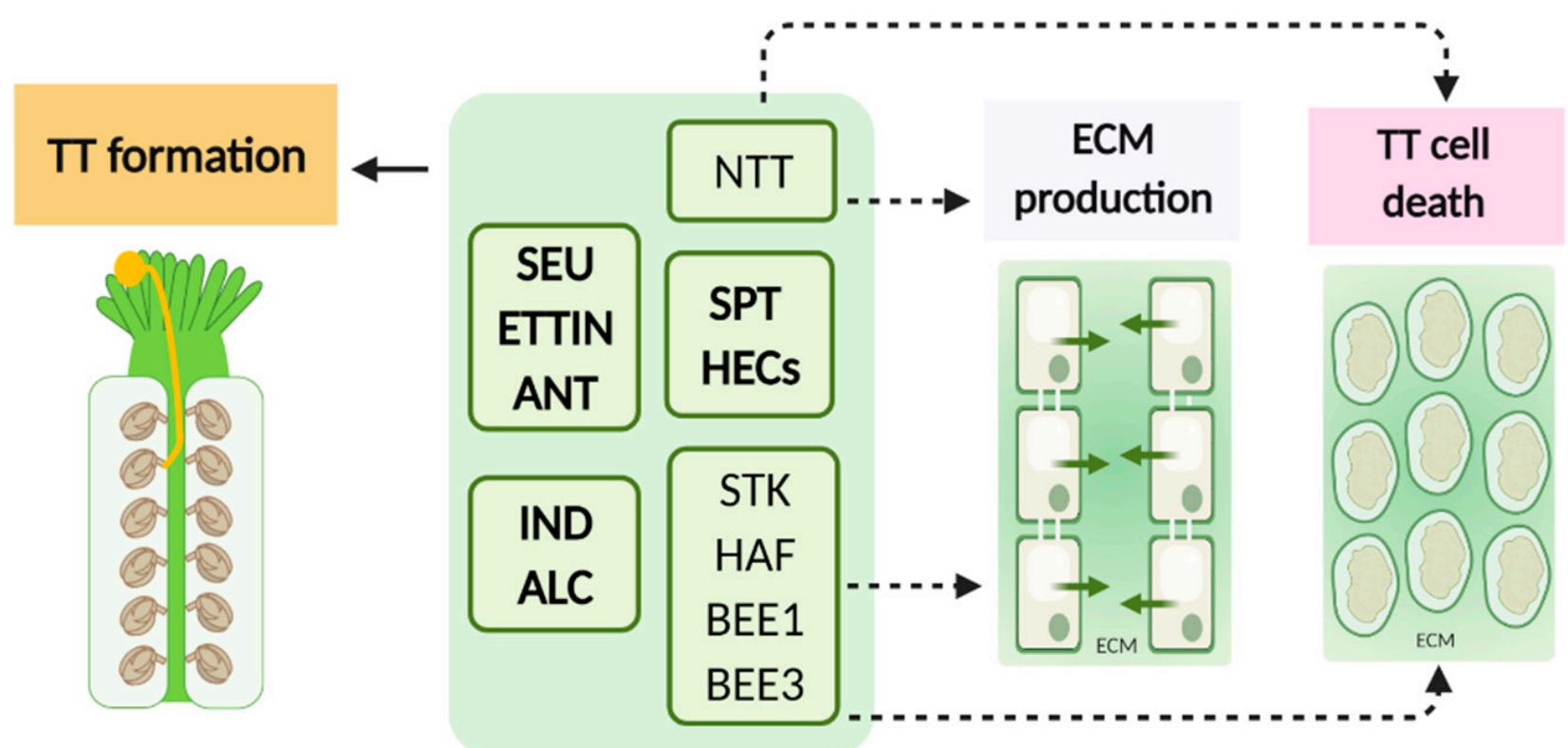

Figure 2. Key players involved in TT formation and development in Arabidopsis thaliana. So far, few main regulators involved in TT formation and development have been identified (NTT, NO TRANSMITTING TRACT; SPT, SPATULA; HEC1, 2, and 3, HECATE1, 2 and 3; STK, SEEDSTICK; HAF, HALF FILLED; BEE1 and BEE3, BRASSINOSTEROID ENHANCED EXPRESSION1 and 3) and a concrete genetic regulatory network has not been fully elucidated. NTT is necessary for TT differentiation. TT development is intimately related to correct carpel fusion and development; thus, several gene products that participate in such processes are also involved in TT formation (SEU, SEUSS; ETTIN; ANT, AINTEGUMENTA; IND, INDEHISCENT; ALC, ALCATRAZ). Proteins are grouped in different boxes according to the way they interact with each other. Created with BioRender.com (accessed on 25 February 2021). 


\section{Key to the Highway: Pollen-Pistil Interactions in the TT}

Several studies have confirmed that PTs grow more slowly, shorter, and less accurately in vitro than through the TT ECM, revealing its importance for PT growth [19,32]. Moreover, PTs grown in vitro are more efficient in targeting ovules if they first grow through a cut stigma and style [39-41]. Since the TT is part of the style, it is reasonable to assume that the PTs growing through the TT acquire the correct competency to respond to ovule attraction signals. Indeed, it has been proven that the transcriptome of PTs grown through a cut stigma and style is very different from the ones grown in vitro, revealing an entirely different set of activated genes involved in cell-cell communication processes [7,42-44]. This tissue seems to serve only one, but fundamental, purpose in the plant: to provide the finest environment for pollen tubes to grow along the pistil until reaching the embryo sacs embedded in the ovules and accomplish double fertilization [45].

In almost every species, the most striking feature of the TT is the massive deposition of ECM among its cells, whose nature and origin was very early on suggested to be a secretory product of the TT cells themselves [6,12]. The composition of this secretory substance, extensively studied in many angiosperms, is composed of carbohydrates, amino acids, glycoproteins, and glycolipids [14-16,46,47]. PTs either grow along the style canal filled with mucilage in the open styles or show an intercellular growth through the ECM of the closed styles [12]. The ECM is proposed to have a nourishing and supporting role for PT growth and is also the place where a large part of the pollen-pistil incompatibility interactions take place, an issue that has been extensively reviewed already $[5,48]$. Besides this, it is also the place where the PTs communicate with the female tissues by several signaling mechanisms in order to obtain guidance cues to grow in the direction of the ovules [49].

Cheung et al. [50] and Wu et al. [51,52] have confirmed the nutritive and adhesive role of the TT in PT growth by identifying AGPs in Nicotiana tabacum, designated as TTS (transmitting-tissue-specific), abundantly present in its ECM. TTS stimulate PT growth in vitro, attract PTs in semi-in vivo assays, and are essential for optimal PT growth in vivo. PTs can deglycosylate these glycoproteins while they grow along the TT, leading to the establishment of a gradient of increasing TTS glycosylation from the top to the bottom of the Nicotiana styles, suggesting that these glycoproteins may be a source of nutrients for PT growth and have a chemotropic guiding effect on growing PTs. The TT of Arabidopsis pistils and many other plant species is extremely rich in AGPs [6,7], which may be acting also as supportive or guiding factors for PT growth. AMOR, a 4-O-methyl-glucuronosyl arabinogalactan (AG) polysaccharide, was identified in Torenia; it is a sporophytic ovular factor that induces PT competency, meaning that PTs which have grown through a cut style become able to respond to female signals [44]. AGPs are strong candidates for the source of this AMOR factor, given their abundance in the female reproductive tract tissues and having this type of sugar. The molecular mechanisms underlying this signaling process are not yet known, and no AMOR molecules have been identified in Arabidopsis pistils, so far. Additionally, and more importantly, the PT growth through the style cannot be fully replaced by adding higher AMOR concentrations, signifying that other signals in the style, not yet identified, are necessary to induce PT competence. For instance, AGP presence in the reproductive tissues has been intensively studied over the years, and several important functions have been assigned to these glycoproteins, but it is still not known how they are integrated into the molecular mechanisms governing PT growth along the pistil tissues. AGPs are extremely glycosylated proteins predicted to be anchored to the plasma membrane by a GPI (glycosylphosphatidylinositol) anchor, attaching them to the extracellular face of the plasma membrane, and their sugar chains are proposed to be their active part in signaling mechanisms [53]. They are highly abundant in the female reproductive tract, all the way from the stigma until the ovule entrance, and their structural features strongly point to their active role as signaling molecules in these tissues [7]. In the $n t t$ mutant plants, the reduced staining for alcian blue indicated also a reduced content in AGPs along the TT, putting forward a possible role for these glycoproteins 
in the TT PCD [19]. In fact, AGPs were, some years ago, suggested to be involved in PCD in plants [54]. Moreover, AGPs were recently described to act as $\mathrm{Ca}^{2+}$ capacitors by storing $\mathrm{Ca}^{2+}$ in the extracellular matrix, and the importance of this ion in reproduction is well described [55]. This capacity to bind $\mathrm{Ca}^{2+}$ seems to be conferred to AGP sugar chains. $\beta$-glucuronic acid (GlcA) residues, which are mainly found terminating the side chains of arabinogalactans (AGs) and which are also part of the AMOR factor described in Torenia, were shown to bind $\mathrm{Ca}^{2+}$ in vitro, in a $\mathrm{pH}$-dependent manner [56]. By studying Arabidopsis mutants in AG $\beta$-glucuronyltransferases, responsible for glucuronidation of AG polysaccharides, Lopez-Hernandez et al. [56] revealed that a reduced content of GlcA on AGs led to deficiencies in plant development and in the spatiotemporal propagation of $\mathrm{Ca}^{2+}$ waves. This study has confirmed that the defects in plant development come from deficiencies in $\mathrm{Ca}^{2+}$ binding by poorly glucuronidated AGPs and, consequently, deficiencies in intracellular $\mathrm{Ca}^{2+}$ signaling. Given the high abundance of AGPs in the reproductive tissues and the special role of $\mathrm{Ca}^{2+}$ in this process, it will be extremely interesting to know what is happening at the reproductive level in these mutants.

Besides TTS, other players were discovered to have adhesion roles in PT growth along the TT, such as pectins and SCA [57]. SCA (stylar cysteine-rich adhesion) encodes a plant lipid transfer protein (LTP) which is secreted from the TT epidermis and is involved in adhesion-mediated PT guidance by forming an adhesive pectin matrix to guide PTs towards the ovules $[58,59]$. SCA must bind to pectin moieties to form an adhesive matrix between PT walls and the TT surface. In lily, chemocyanin, a small cell wall protein, was identified as a chemotropic compound from the stigma able to reorient PT growth in in vitro assays and in the stigma, an activity enhanced by the cooperation with SCA [60]. In A. thaliana, a plantacyanin gene sharing $86.8 \%$ similarity to lily, chemocyanin is abundantly present in the TT and is proposed to act in PT growth along this tissue [61]. Likewise in Arabidopsis, LTP5, a SCA-like molecule, was identified has having a role in PT tip growth, also by interacting with pectins [62]. SCA from the pistil is proposed to have both an adhesive and guiding role during PT growth, and pectin, a cell wall component highly abundant in the TT cell walls, plays an important role in this step of plant reproduction; VANGUARD1 (VGD) is a pectin methylesterase (PME) from PTs proposed to act during PT-pistil interactions by modifying TT cell walls. VGD1 is thought to enhance PT interaction with the transmitting tract. Demethylesterification of TT pectins by this PME may contribute to degradation and loosening of its cell wall. This may happen due to the release of protons during random homogalacturonan demethylesterification, which promotes the action of endopolygalacturonases contributing to the cell wall loosening and degradation, thus facilitating its interactions with the TT ECM $[63,64]$. Recently, a Zea mays female gene encoding a pistil-expressed pectin methylesterase 38 (PME38) homolog was identified and proposed to be involved in a mechanism for reproductive isolation in diverging plant populations of maize and teosintes, in which the PT cell wall is modified by the female tissues, consequently preventing continued PT growth in the TT and fertilization [65]. The $\gamma$-amino butyric acid (GABA) was also shown to have a role in PT growth, in Arabidopsis TT [66]. In vitro, GABA stimulates PT growth at lower concentrations and inhibits its elongation at higher concentrations. The gene POLLEN ON PISTIL 2 (POP2) encodes a GABA transaminase which is involved in degrading GABA and establishing an increasing GABA gradient along the TT, believed to sustain PT guidance. GABA was proposed to mediate PT growth by modulation of putative $\mathrm{Ca}^{2+-}$ permeable channels on the plasma membranes of tobacco PTs [67]. $\mathrm{Ca}^{2+}$ has been shown over the years to play vital roles during the reproductive process, particularly during PT growth [49]. Another pistil amino acid involved in regulating PT growth by modulating $\left[\mathrm{Ca}^{2+}\right]$ in PTs is D-serine, which facilitates PT growth along the TT by inducing the $\mathrm{Ca}^{2+}$-permeable glutamate receptor-like channels (GLRs) at the PT tip plasma membranes [68]. Plant hormones may also play important roles during this step of PT growth. Vogler et al. [69] revealed that epibrassinolide, a brassinosteroid, enhances PT growth in vitro and suggests that cells from the TT provide brassinosteroid compounds to promote PT growth. 
Finally, at some point, the PTs have to turn their growth direction towards the ovules and exit the TT fast lane. Although important PT components have been thoroughly described to act in PT change of direction [70], we do not know, yet, which kind of signal supports this change in growth direction. LUREs, a group of defensin-like polypeptides (DEFL), are known to act as PT attractants produced by the synergids in the ovules [71,72], but these are short-range signals and would not be capable of triggering PTs' exit from the TT.

One of the topics which started to be tackled recently $[36,37]$ and that will be surely further explored is the possible role of the TT regulators in affecting gene expression patterns of TT cell wall polysaccharides [73], since cell wall remodeling plays an essential role during PT growth along this tissue, being directly related to its nutritional, supportive, and guiding roles.

\section{Concluding Remarks}

The TT serves different and fundamental functions in PT growth, acting as a supportive, adhesive, nutritive, and guiding structure for PT growth, involving PCD, cell wall remodeling, and cell-cell communication processes. Although several genetic mutations affecting TT development have been discovered over the years, little information is available about the nature of PT growth-promoting ECM components along this important tissue. Insights pertaining to the nature of these factors and the mechanisms underlying the PT-pistil interaction processes remain sparse due to the difficulty of accessing and manipulating the female sporophytic tissues enclosed in the pistil.

In recent years, research in the plant reproductive field has led to the discovery of innumerous players involved in the reproductive process. Most of the components discovered to be involved in pollen-pistil interactions are, nevertheless, molecular players present in the pollen and pollen tube, due to the facility inherent to its study. This was not the focus of the present review, and there are several reviews describing this in more detail, such as in Johnson et al. [49], Lopes et al. [74], and Mizuta and Higashiyama [10]. We aimed at gathering most of the information available on the female molecular players involved in the role of the TT for PT growth and guidance into the ovules (Figure 3), which greatly influences fertilization success. The importance of this step in the reproductive process demands further research. Identified transcription factors might serve as tools for future studies aiming at identifying the ECM TT components involved in pollen-pistil interactions. A better understanding of the molecular processes taking place during this crucial step of plant reproduction will not only be a great achievement in terms of advancing our knowledge of plant reproduction but will also enable us to eventually increase PT growth and fertilization efficiency and facilitate the generation of agronomically interesting interspecific hybrids. 


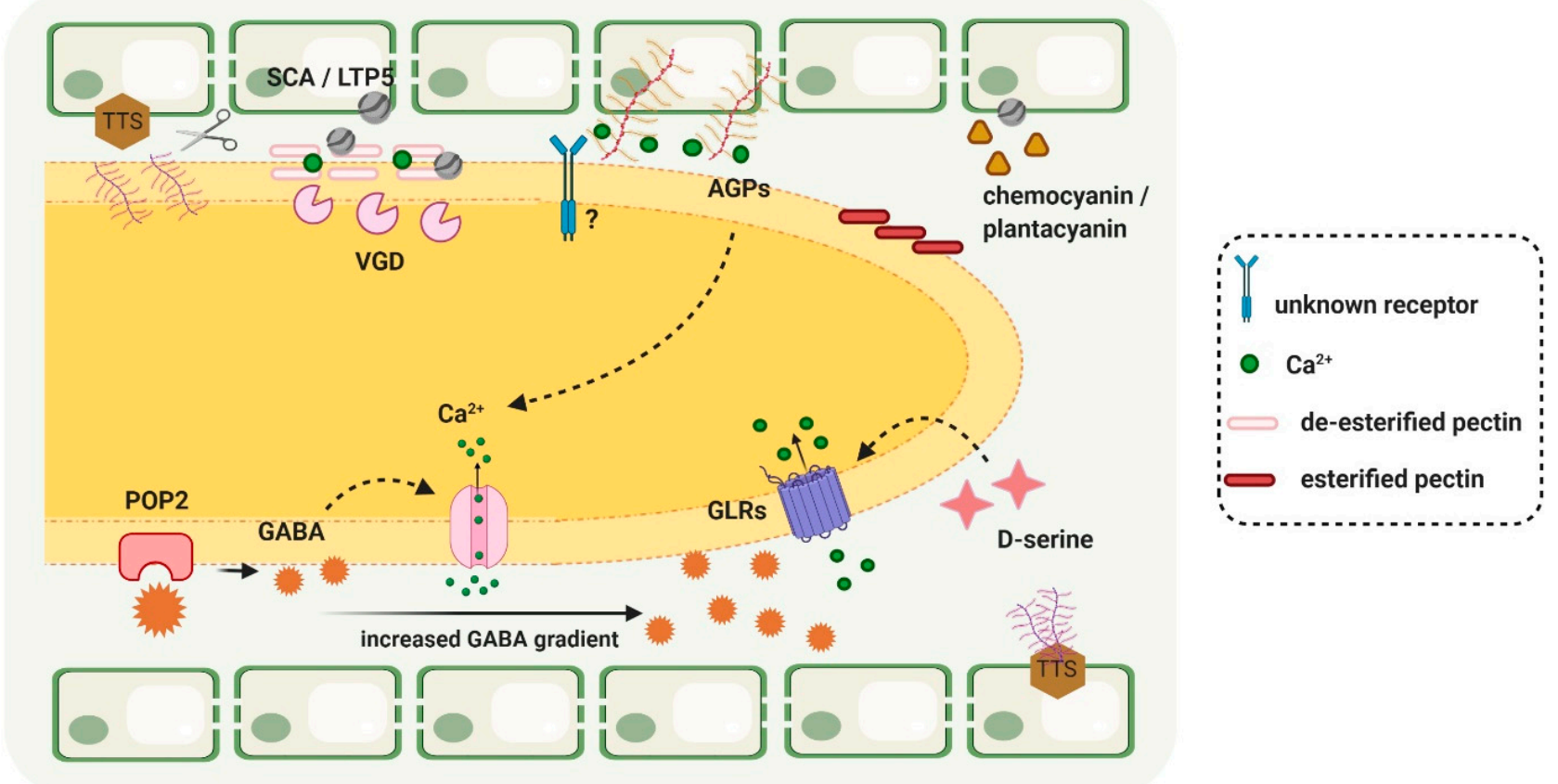

Figure 3. Main signaling molecules involved in the communication between pollen tube and transmitting tract during its growth in this tissue, towards the ovule. This image aims to focus mainly on the transmitting-tract-secreted signals, rather than on the signals generated by the pollen tube, well described in many reviews. TTS (transmitting-tissue-specific) is shown at the surface of the TT cells either still intact or being deglycosylated (scissors) by the growing PT. The glycosylated TTS is decreased after the arrival of the PTs in the TT, thereby establishing a gradient of increasing TTS glycosylation from the top to the bottom of the style. AGPs (arabinogalactan proteins) are also present in the TT cells and ECM and are thought to play essential roles in PT growth, by some signaling pathway which remains to be unraveled. AGPs are represented by the branched glycans acting as $\mathrm{Ca}^{2+}$ reservoirs (green dots), which are probably involved in $\mathrm{Ca}^{2+}$ signaling pathways in the PT. LTP (lipid transfer protein) represents the SCA, stylar cysteine-rich adhesion molecule, secreted by the TT cells, forming an adhesive matrix with pectins between the PT and the TT surface. Chemocyanin is also shown, which has a chemotropic guidance effect on PTs by acting together with SCA. VGD1 (VANGUARD1) is a pectin methylesterase (PME) from the PT, acting on pectin demethyesterification and leading to TT cell wall loosening to facilitate PT growth, possibly by coordinated action with endopolygalacturonases. A GABA ( $\gamma$-amino butyric acid) gradient created by male POP2 (POLLEN ON PISTIL 2), a GABA transaminase, is thought to provide cues for PT growth along the TT. Besides this, GABA may modulate Ca ${ }^{2+}$ channels from the PT, influencing the dynamic extracellular and intracellular $\mathrm{Ca}^{2+}$ gradient essential for PT growth along the pistil tissues. Also involved in $\mathrm{Ca}^{2+}$ gradient changes is D-serine from the pistil tissues, which induces $\mathrm{Ca}^{2+}$ permeable GLRs (glutamate receptor-like channels) at the PT tip. Created with BioRender.com (accessed on 25 February 2021).

Author Contributions: A.M.P. and D.M. conceptualized, organized, and prepared this manuscript; S.C. and S.M. contributed to writing and reviewing the manuscript. All authors have read and agreed to the published version of the manuscript.

Funding: A.M.P.'s and S.M.'s project has received funding from the European Union's Horizon 2020 MSCA-IF-2016-Individual Fellowships programme under the Marie Skłodowska-Curie grant agreement no. 753328. D.M.'s research was supported by an FCT PhD grant, SFRH/BD/143557/2019. S.C.'s research has received funding from the European Union's Horizon 2020 MSCA-RISE-2015 programme under the Marie Skłodowska-Curie grant agreement no. 690946 and has received funding from an FCT SeedWheels FCT Project-POCI-01-0145-FEDER-027839.

Conflicts of Interest: The authors declare that the research was conducted in the absence of any commercial or financial relationships that could be construed as a potential conflict of interest.

\section{References}

1. Russell, S.D. Double Fertilization. Adv. Appl. Microbiol. 1992, 140, 357-388. [CrossRef]

2. Yadegari, R.; Drews, G. Female gametophyte development. Plant Cell 2004, 16, S133-S141. [CrossRef] [PubMed] 
3. Palanivelu, R.; Tsukamoto, T. Pathfinding in angiosperm reproduction: Pollen tube guidance by pistils ensures successful double fertilization. Wiley Interdiscip. Rev. Dev. Biol. 2012, 1, 96-113. [CrossRef]

4. Beale, K.M.; Johnson, M.A. Speed dating, rejection, and finding the perfect mate: Advice from flow-ering plants. Curr. Opin. Plant Biol. 2013, 16, 590-597. [CrossRef]

5. Dresselhaus, T.; Franklin-Tong, N. Male-Female Crosstalk during Pollen Germination, Tube Growth and Guidance, and Double Fertilization. Mol. Plant 2013, 6, 1018-1036. [CrossRef]

6. Pereira, A.M.; Masiero, S.; Nobre, M.S.; Costa, M.L.; Solís, M.-T.; Testillano, P.S.; Sprunck, S.; Coimbra, S. Differential expression patterns of arabinogalactan proteins in Arabidopsis thaliana re-productive tissues. J. Exp. Bot. 2014, 65, 5459-5471. [CrossRef]

7. Pereira, A.M.; Lopes, A.L.; Coimbra, S.V. Arabinogalactan Proteins as Interactors along the Crosstalk between the Pollen Tube and the Female Tissues. Front. Plant Sci. 2016, 7, 1895. [CrossRef] [PubMed]

8. Sprunck, S. Twice the fun, double the trouble: Gamete interactions in flowering plants. Curr. Opin. Plant Biol. 2020, 53, 106-116. [CrossRef]

9. Higashiyama, T.; Takeuchi, H. The mechanism and key molecules involved in pollen tube guid-ance. Annu. Rev. Plant Biol. 2015, 66, 393-413. [CrossRef]

10. Mizuta, Y.; Higashiyama, T. Chemical signaling for pollen tube guidance at a glance. J. Cell Sci. 2018, 131, jcs208447. [CrossRef]

11. Sage, T.L.; Hristova-Sarkovski, K.; Koehl, V.; Lyew, J.; Pontieri, V.; Bernhardt, P.; Weston, P.; Bagha, S.; Chiu, G. Transmitting tissue architecture in basal-relictual angiosperms: Implications for transmitting tissue origins. Am. J. Bot. 2009, 96, 183-206. [CrossRef]

12. Sassen, M.M.A. The stylar transmitting tissue. Acta Bot. Neerl. 1974, 23, 99-108. [CrossRef]

13. Erbar, C. Pollen Tube Transmitting Tissue: Place of Competition of Male Gametophytes. Int. J. Plant Sci. 2003, 164, S265-S277. [CrossRef]

14. Mascarenhas, J.P. The biochemistry of angiosperm pollen development. Bot. Rev. 1975, 41, 259-314. [CrossRef]

15. Mascarenhas, J.P. Molecular mechanisms of pollen tube growth and differentiation. Plant Cell 1993, 5, 1303. [CrossRef]

16. Heslopharrison, J. Pollen Germination and Pollen-Tube Growth. Adv. Appl. Microbiol. 1987, 107, 1-78. [CrossRef]

17. Johnson, M.A.; Preuss, D. Plotting a course: Multiple signals guide pollen tubes to their targets. Dev. Cell 2002, 2, 273-281. [CrossRef]

18. Johnson, M.A.; Lord, E. Extracellular guidance cues and intracellular signaling pathways that di-rect pollen tube growth. In The Pollen Tube; Springer: Berlin/Heidelberg, Germany, 2006; pp. 223-242.

19. Crawford, B.C.; Yanofsky, M.F. The Formation and Function of the Female Reproductive Tract in Flowering Plants. Curr. Biol. 2008, 18, R972-R978. [CrossRef]

20. Bowman, J.L.; Baum, S.F.; Eshed, Y.; Putterill, J.; Alvarez, J. 4 Molecular Genetics of Gynoecium Development in Arabidopsis. Protein Kinases Dev. Dis. 1999, 45, 155-205. [CrossRef]

21. Alvarez, J.; Smyth, D.R. Crabs claw and spatula genes regulate growth and pattern for-mation during gynoecium development in Arabidopsis thaliana. Int. J. Plant Sci. 2002, 163, 17-41. [CrossRef]

22. Reyes-Olalde, J.I.; Zuñiga-Mayo, V.M.; Montes, R.A.C.; Marsch-Martínez, N.; De Folter, S. Inside the gynoecium: At the carpel margin. Trends Plant Sci. 2013, 18, 644-655. [CrossRef]

23. Ciampolini, F.; Shivanna, K.R.; Cresti, M. Organization of the Stigma and Transmitting Tissue of Rice, Oryza sativa (L.). Plant Biol. 2001, 3, 149-155. [CrossRef]

24. Wang, H.; Wu, H.-M.; Cheung, A.Y. Pollination induces mRNA poly(A) tail-shortening and cell deterioration in flower transmitting tissue. Plant J. 1996, 9, 715-727. [CrossRef] [PubMed]

25. Crawford, B.C.; Ditta, G.; Yanofsky, M.F. The NTT gene is required for transmitting-tract devel-opment in carpels of Arabidopsis thaliana. Curr. Biol. 2007, 17, 1101-1108. [CrossRef] [PubMed]

26. A Sessions, R.; Zambryski, P.C. Arabidopsis gynoecium structure in the wild and in ettin mutants. Development 1995, 121, 1519-1532. [PubMed]

27. Kuusk, S.; Sohlberg, J.J.; Magnus Eklund, D.; Sundberg, E.J. Functionally redundant SHI family genes regulate Arabidopsis gynoecium development in a dose-dependent manner. Plant J. 2006, 47, 99-111. [CrossRef]

28. Alvarez, J.; Smyth, D.R. Crabs claw and spatula, two arabidopsis genes that control carpel development in parallel with agamous. Development 1999, 126, 2377-2386.

29. Azhakanandam, S.; Nole-Wilson, S.; Bao, F.; Franks, R.G. Seuss and aintegumenta Mediate Patterning and Ovule Initiation during Gynoecium Medial Domain Development. Plant Physiol. 2008, 146, 1165-1181. [CrossRef]

30. Groszmann, M.; Paicu, T.; Alvarez, J.P.; Swain, S.M.; Smyth, D.R. Spatula and alcatraz, are partially redundant, functionally diverging bHLH genes required for Arabidopsis gynoecium and fruit development. Plant J. 2011, 68, 816-829. [CrossRef]

31. Kay, P.; Groszmann, M.; Ross, J.J.; Parish, R.W.; Swain, S.M. Modifications of a conserved regulatory network involving INDEHISCENT controls multiple aspects of reproductive tissue development in Arabidopsis. New Phytol. 2012, 197, 73-87. [CrossRef] [PubMed]

32. Lennon, K.A.; Roy, S.; Hepler, P.K.; Lord, E.J. The structure of the transmitting tissue of Ara-bidopsis thaliana (L.) and the path of pollen tube growth. Sex. Plant Reprod. 1998, 11, 49-59. [CrossRef]

33. Gremski, K.; Ditta, G.; Yanofsky, M.F. The HECATE genes regulate female reproductive tract de-velopment in Arabidopsis thaliana. Developtment 2007, 134, 3593-3601.

34. Crawford, B.C.; Yanofsky, M.F. Half filled promotes reproductive tract development and ferti-lization efficiency in Arabidopsis thaliana. Development 2011, 138, 2999-3009. [CrossRef] [PubMed] 
35. Di Marzo, M.; Roig-Villanova, I.; Zanchetti, E.; Caselli, F.; Gregis, V.; Bardetti, P.; Chiara, M.; Guazzotti, A.; Caporali, E.; Mendes, M.A.; et al. MADS-Box and bHLH Transcription Factors Co-ordinate Transmitting Tract Development in Arabidopsis thaliana. Front. Plant Sci. 2020, 11, 526. [CrossRef] [PubMed]

36. Herrera-Ubaldo, H.; Lozano-Sotomayor, P.; Ezquer, I.; Di Marzo, M.; Montes, R.A.C.; Gómez-Felipe, A.; Pablo-Villa, J.; DiazRamirez, D.; Ballester, P.; Ferrándiz, C. New roles of no transmitting tract and seedstick during medial domain development in Arabidopsis fruits. Development 2019, 146. [CrossRef]

37. Di Marzo, M.; Herrera-Ubaldo, H.; Caporali, E.; Novák, O.; Strnad, M.; Balanzà, V.; Ezquer, I.; Mendes, M.A.; de Folter, S.; Colombo, L. Seedstick controls Arabidopsis fruit size by regulat-ing cytokinin levels and fruitfull. Cell. Rep. 2020, 30, 2846-2857. [CrossRef]

38. Cerbantez-Bueno, V.E.; Zúñiga-Mayo, V.M.; Reyes-Olalde, J.I.; Lozano-Sotomayor, P.; Herrera-Ubaldo, H.; Marsch-Martinez, N.; De Folter, S. Redundant and Non-redundant Functions of the AHK Cytokinin Receptors During Gynoecium Development. Front. Plant. Sci. 2020, 11, 568277. [CrossRef]

39. Higashiyama, T.; Kuroiwa, H.; Kawano, S.; Kuroiwa, T.; Prymakowska-Bosak, M.; Przewloka, M.R.; Ślusarczyk, J.; Kuraś, M.; Lichota, J.; Kiliańczyk, B.; et al. Guidance in Vitro of the Pollen Tube to the Naked Embryo Sac of Torenia fournieri. Plant. Cell 1998, 10, 2019-2031. [CrossRef]

40. Palanivelu, R.; Preuss, D. Distinct short-range ovule signals attract or repel Arabidopsis thaliana pollen tubes in vitro. BMC Plant. Biol. 2006, 6, 7. [CrossRef] [PubMed]

41. Zhong, S.; Qu, L.-J. Peptide/receptor-like kinase-mediated signaling involved in male-female in-teractions. Curr. Opin. Plant Biol. 2019, 51, 7-14. [CrossRef]

42. Qin, Y.; Leydon, A.R.; Manziello, A.; Pandey, R.; Mount, D.; Denic, S.; Vasic, B.; Johnson, M.A.; Palanivelu, R. Penetration of the Stigma and Style Elicits a Novel Transcriptome in Pollen Tubes, Pointing to Genes Critical for Growth in a Pistil. PLoS Genet. 2009, 5, e1000621. [CrossRef] [PubMed]

43. Tung, C.-W.; Dwyer, K.G.; Nasrallah, M.E.; Nasrallah, J.B. Genome-Wide Identification of Genes Expressed in Arabidopsis Pistils Specifically along the Path of Pollen Tube Growth. Plant. Physiol. 2005, 138, 977-989. [CrossRef] [PubMed]

44. Mizukami, A.G.; Inatsugi, R.; Jiao, J.; Kotake, T.; Kuwata, K.; Ootani, K.; Okuda, S.; Sankaranarayanan, S.; Sato, Y.; Maruyama, D.; et al. The AMOR Arabinogalactan Sugar Chain Induces Pollen-Tube Competency to Respond to Ovular Guidance. Curr. Biol. 2016, 26, 1091-1097. [CrossRef] [PubMed]

45. Bell, J.; Hicks, G. Transmitting tissue in the pistil of tobacco: Light and electron microscopic obser-vations. Planta 1976, 131, 187-200. [CrossRef]

46. Kroh, M.; Van Bakel, C. Incorporation of label into the intercellular substance of stylar transmit-ting tissue from Petunia pistils labeled with tritiated myo-inositol. An electronmicroscopic autora-diographic study. Acta Bot. Neerl. 1973, 22, 106-111. [CrossRef]

47. Lord, E.; Sanders, L. Roles for the extracellular matrix in plant development and pollination: A special case of cell movement in plants. Dev. Biol. 1992, 153, 16-28. [CrossRef]

48. Fujii, S.; Kubo, K.-I.; Takayama, S. Non-self- and self-recognition models in plant self-incompatibility. Nat. Plants 2016, 2, 16130. [CrossRef] [PubMed]

49. Johnson, M.A.; Harper, J.F.; Palanivelu, R. A fruitful journey: Pollen tube navigation from germination to fertilization. Annu. Rev. Plant Biol. 2019, 70, 809-837. [CrossRef]

50. Cheung, A.Y.; Wang, H.; Wu, H.-M. A floral transmitting tissue-specific glycoprotein attracts pollen tubes and stimulates their growth. Cell 1995, 82, 383-393. [CrossRef]

51. Wu, H.-M.; Wang, H.; Cheung, A.Y. A pollen tube growth stimulatory glycoprotein is deglycosylated by pollen tubes and displays a glycosylation gradient in the flower. Cell 1995, 82, 395-403. [CrossRef]

52. Wu, H.M.; Wong, E.; Ogdahl, J.; Cheung, A.Y. A pollen tube growth-promoting arabinogalactan pro-tein from Nicotiana alata is similar to the tobacco TTS protein. Plant J. 2000, 22, 165-176. [CrossRef]

53. Ma, Y.; Yan, C.; Li, H.; Wu, W.; Liu, Y.; Wang, Y.; Chen, Q.; Ma, H. Bioinformatics Prediction and Evolution Analysis of Arabinogalactan Proteins in the Plant Kingdom. Front. Plant. Sci. 2017, 8, 66. [CrossRef]

54. Gao, M.; Showalter, A.M. Yariv reagent treatment induces programmed cell death in Arabidopsis cell cultures and implicates arabinogalactan protein involvement. Plant J. 1999, 19, 321-331. [CrossRef]

55. Lamport, D.T.A.; Varnai, P.; Seal, C.E. Back to the future with the AGP-Ca2+ flux capacitor. Ann. Bot. 2014, 114, 1069-1085. [CrossRef] [PubMed]

56. Lopez-Hernandez, F.; Tryfona, T.; Rizza, A.; Xiaolan, L.Y.; Harris, M.O.; Webb, A.A.; Kotake, T.; Dupree, P.J. Calcium binding by arabinogalactan polysaccharides is important for normal plant de-velopment. Plant Cell 2020, 32, 3346-3369. [CrossRef] [PubMed]

57. Lord, E.; Walling, L.; Jauh, G. Cell Adhesion in Plants and Its Role in pollination. Membranes: Specialized Functions in Plants; BIOS Scientific Publishers: Oxford, UK, 1996; pp. 21-37.

58. Mollet, J.-C.; Park, S.-Y.; Nothnagel, E.A.; Lord, E.M. A lily stylar pectin is necessary for pollen tube adhesion to an in vitro stylar matrix. Plant Cell 2000, 12, 1737-1749. [CrossRef] [PubMed]

59. Park, S.-Y.; Jauh, G.-Y.; Mollet, J.-C.; Eckard, K.J.; Nothnagel, E.A.; Walling, L.L.; Lord, E.M. A lipid transfer-like protein is necessary for lily pollen tube adhesion to an in vitro stylar matrix. Plant Cell 2000, 12, 151-163. [PubMed]

60. Kim, S.; Mollet, J.-C.; Dong, J.; Zhang, K.; Park, S.-Y.; Lord, E.M. Chemocyanin, a small basic protein from the lily stigma, induces pollen tube chemotropism. Proc. Natl. Acad. Sci. USA 2003, 100, 16125-16130. [CrossRef] 
61. Dong, J.; Kim, S.T.; Lord, E.M. Plantacyanin Plays a Role in Reproduction in Arabidopsis. Plant. Physiol. 2005, 138, 778-789. [CrossRef] [PubMed]

62. Chae, K.; Kieslich, C.A.; Morikis, D.; Kim, S.-C.; Lord, E.M. A gain-of-function mutation of Ara-bidopsis lipid transfer protein 5 disturbs pollen tube tip growth and fertilization. Plant Cell 2009, 21, 3902-3914. [CrossRef]

63. Jiang, L.; Yang, S.-L.; Xie, L.-F.; San Puah, C.; Zhang, X.-Q.; Yang, W.-C.; Sundaresan, V.; Ye, D.J. VANGUARD1 encodes a pectin methylesterase that enhances pollen tube growth in the Ara-bidopsis style and transmitting tract. Plant Cell 2005, 17, 584-596. [CrossRef]

64. Goldberg, R.; Morvan, C.; Jauneau, A.; Jarvis, M. Methyl-esterification, de-esterification and gela-tion of pectins in the primary cell wall. In Progress in Biotechnology; Elsevier: Amsterdam, The Netherlands, 1996; Volume 14, pp. 151-172.

65. Lu, Y.; Lauter, A.N.M.; Makkena, S.; Scott, M.P.; Evans, M.M.S. Insights into the molecular control of cross-incompatibility in Zea mays. Plant. Reprod. 2020, 33, 117-128. [CrossRef] [PubMed]

66. Palanivelu, R.; Brass, L.; Edlund, A.F.; Preuss, D. Pollen Tube Growth and Guidance Is Regulated by POP2, an Arabidopsis Gene that Controls GABA Levels. Cell 2003, 114, 47-59. [CrossRef]

67. Yu, G.-H.; Zou, J.; Feng, J.; Peng, X.-B.; Wu, J.-Y.; Wu, Y.-L.; Palanivelu, R.; Sun, M.-X.J. Exoge-nous $\gamma$-aminobutyric acid (GABA) affects pollen tube growth via modulating putative $\mathrm{Ca} 2+$-permeable membrane channels and is coupled to negative regulation on glutamate decarboxylase. J. Exp. Bot. 2014, 65, 3235-3248. [CrossRef]

68. Michard, E. Channels in Pollen 2+ Like Genes Form Ca- Glutamate Receptor. Science 2011, 1201101, 332.

69. Vogler, F.; Schmalzl, C.; Englhart, M.; Bircheneder, M.; Sprunck, S. Brassinosteroids promote Ar-abidopsis pollen germination and growth. Plant Repro. 2014, 27, 153-167. [CrossRef]

70. Lu, Y.; Chanroj, S.; Zulkifli, L.; Johnson, M.A.; Uozumi, N.; Cheung, A.; Sze, H. Pollen Tubes Lacking a Pair of K+ Transporters Fail to Target Ovules in Arabidopsis. Plant. Cell 2011, 23, 81-93. [CrossRef]

71. Okuda, S.; Tsutsui, H.; Shiina, K.; Sprunck, S.; Takeuchi, H.; Yui, R.; Kasahara, R.D.; Hamamura, Y.; Mizukami, A.; Susaki, D.; et al. Defensin-like polypeptide LUREs are pollen tube attractants secreted from synergid cells. Nat. Cell Biol. 2009, 458, 357-361. [CrossRef] [PubMed]

72. Takeuchi, H.; Higashiyama, T. Tip-localized receptors control pollen tube growth and LURE sens-ing in Arabidopsis. Nature 2016, 531, 245-248. [CrossRef] [PubMed]

73. Herrera-Ubaldo, H.; de Folter, S. Exploring cell wall composition and modifications during the development of the gynoecium medial domain in Arabidopsis. Front. Plant Sci. 2018, 9, 454. [CrossRef]

74. Lopes, A.L.; Moreira, D.; Ferreira, M.J.; Pereira, A.M.; Coimbra, S. Insights into secrets along the pollen tube pathway in need to be discovered. J. Exp. Bot. 2019, 70, 2979-2992. [CrossRef] [PubMed] 